\title{
PERTANGGUNGJAWABAN KORPORASI TERHADAP TINDAK PIDANA HUMAN TRAFFICKING DI INDONESIA
}

\author{
Muh Abdul Qudus \\ Prodi Magister Ilmu Hukum, Fakultas Hukum, Universitas Diponegoro, \\ Semarang \\ Pujiyono \\ Dosen Fakultas Hukum, Universitas Diponegoro, Semarang \\ Jalan Imam Bardjo, S.H. No.1-3, Kampus Pleburan, Semarang 50241
}

\begin{abstract}
ABSTRAK
Permasalahan terkait Hak Asasi Manusia di Indonesia adalah tindak pidana perdagangan orang yang dilakukan oleh korporasi. Perdagangan orang adalah bentuk modern dari perbudakan manusia dan juga merupakan salah satu bentuk perlakuan terburuk dari pelanggaran harkat dan martabat manusia. Namun, perkembanggannya terdapat kesulitan terhadap penegakan hukum terkait korporasi yang melakukan tindak pidana perdagangan orang. Metode penelitian digunakan adalah metode penelitian yuridis normatif dengai memakai data sekunder untuk dianalisis secara kualitatif. Hasil dari penelitian ini menunjukan Korporasi sebagai subjek hukum pidana dapat dipersamakan dengan manusia, karena di dalamnya terdapat hak dan kewajiban yang diberikan oleh hukum dan karenanya kecakapan korporasi juga dipersamakan dengan kecakapan manusia. Pengaturan mengenai pertanggungjawaban korporasi telah diatur dalam Undang-Undang Nomor 21 Tahun 2007 tentang Pemberantasan Tindak Pidana Perdagangan Orang, korporasi dapat dimintakan pertanggungjawbannya apabila melakukan tindak pidana perdagangan orang dengan terpenuhinya syarat pertanggungjawaban pidana secara umum seperti adanya kemampuan bertanggungjawab, adanya kesalahan baik kesengajaan maupun kealpaan, tidak adanya hal-hal yang dijadikan alasan penghapus pidana.
\end{abstract}

Kata Kunci: Pertanggungjawaban Korporasi, Human Trafficking

\section{ABSTRACT}

Problems related to human rights in Indonesia are criminal acts of human trafficking committed by corporations. Trafficking in persons is a modern form of human slavery and is also one of the worst forms of treatment of violations of human dignity. However, the development has difficulties with law enforcement related to corporations that commit criminal acts of trafficking. The research method used is a normative juridical research method using secondary data to be analyzed qualitatively. The results of this study show that corporations as subjects of criminal law can be equated with humans, because there are rights and obligations given by law and therefore corporate skills are also equated with human skills. The regulation regarding corporate responsibility has been regulated in Law Number 21 of 2007 concerning the Eradication of Trafficking in Persons, corporations can be held liable if they commit criminal acts of trafficking by fulfilling the requirements of criminal liability in general such as the ability to be responsible, mistakes and intentions, absence of matters that are used as reasons for criminal offenses.

Keywords: Corporate Accountability, Human Trafficking 


\section{Pendahuluan}

Secara kodrati, manusia memiliki hak yang sama dan melekat pada diri orang itu sendiri tanpa adanya pengecualian. Hak tersebut adalah untuk hidup, ha katas keamanan, hak bebas dari segala macam penindasan dan hal lainnya yang secara universal disebut sebagai Hak Asasi Manusia (HAM) (Takariawan \& Putri, 2018). Istilah HAM itu sendiri ditentukan dalam hakikat kemanusiaan dan demi kemanusiaan, karena HAM merupakan hak dasar seluruh umat manusia sebagai anugrah Tuhan Yang Maha Esa (Takariawan \& Putri, 2018).

Terkait dengan perlindungan HAM, secara konstitusional, setiap warga negara dijamin haknya untuk bekerja baik dalam maupun luar negeri sebagaimana termaktub dalam Pasal 27 Ayat 2 UUD 1945. Tiap-tiap warga negara berhak atas pekerjaan dan penghidupan yang layak bagi kemanusiaan, sehingga tidak boleh ada seorangpun yang menghalangi warga negara Indonesia untuk bekerja diluar negeri. Maka dari itu, bermigrasi secara aman adalah hak asasi setiap warga negara Indonesia. Migrasi aman merupakan migrasi tenaga kerja ke luar negeri secara bermartabat baik proses keberangkatannya melalui pemerintah, swasta maupun mandiri, negara wajib menghormati, melindungi dan memenuhi hakhaknya baik ketika sebelum berangkat, ketika bekerja hingga pulang kembali ke tanah air (Nurharsono, Koor. Divisi BH, Migrant CARE Jkt, 2018).

$$
\text { Salah satu permasalahan }
$$
terkait HAM di Indonesia adalah tindak pidana perdagangan orang (human trafficking). Perdagangan orang adalah bentuk modern dari perbudakan manusia dan juga merupakan salah satu bentuk perlakuan terburuk dari pelanggaran harkat dan martabat manusia. Sebaran kasus WNI korban tindak pidana human trafficking di luar negeri dari tahun 2015 hingga November 2018 berjumlah 1717 total kasus. Rincian kasus tersebut tersebar di kawasan Asia memiliki 722 kasus, Timur Tengah memiliki 691 kasus, Afrika memiliki 235 kasus Amerika dan Karibia memiliki 11 kasus, Eropa memiliki 23 kasus dan Oceana memiliki 35 kasus. Dari jumlah kasus di atas, sebagai besar modus tindak pidana human trafficking adalah undocument atau penyalahgunaan visa seperti berkaitan visa umroh, visa ziarah, visa kunjungan dan sebagainya. Modus tindak pidana human trafficking lainya adalah penipuan negara tujuan kerja dan pengantin pesanan (mail bride order), pemalsuan identitas korban, penipuan dengan modus magang/belajar dan pengiriman jalur tikus di SebatikNunukan, Entikong dan daerah Batam (Widowati, Kasubit Kawasan III, Dit. Perlindungan WNI dan BHI, KEMENLU, 2018).

Berdasarkan bukti empiris, korban diperdagangkan tidak hanya 
untuk tujuan pelacuran atau bentuk eksploitasi seksual lainnya, tetapi juga mencakup bentuk eksploitasi lain, misalnya kerja paksa atau pelayanan paksa, perbudakan, atau praktik serupa perbudakan itu. Pelaku tindak pidana perdagangan orang melakukan perekrutan, pengangkutan, pemindahan, penyembunyian, atau penerimaan orang untuk tujuan menjebak, menjerumuskan, atau memanfaatkan orang tersebut dalam praktik eksploitasi dengan segala bentuknya dengan ancaman kekerasan, penggunaan kekerasan, penculikan, pemalsuan, penipuan, penyalahgunaan kekuasaan atau posisi rentan, atau memberi bayaran atau manfaat sehingga memperoleh persetujuan dari orang yang memegang kendali atas korban (Nugroho, 2018).

Di era globalisasi dan modern ini tidak menutup kemungkinan kejahatan human trafficking dilakukan oleh korporasi. Sering sekali penyalur jasa TKI illegal menggunakan modus usaha baik berbentuk CV, PT ataupun lain lain untuk melancarkan niat jahat melakukan human trafficking (Hanim \& Prakoso, 2015). Kewenangan untuk menjatuhkan sanksi kepada korporasi sudah diberikan secara eksplisit dalam rumusan Undang-Undang N0 21 tahun 2007 tentang Pemberantasan Tindak Pidana Perdagangan Orang. Sebagai upaya untuk menanggulangi tindak pidana perdagangan orang yang dilakukan oleh korporasi, maka UU ini telah mengatur mengenai manusia dan korporasi sebagai subjek hukum. Ditempatkanya korporasi dalam subjek hukum tindak pidana human trafficking dapat memberikan harapan serta optimisme bagi upaya pengusutan dan pemberantasan tindak pidana human trafficking.

Mengingat penelitian sebelumnya yang terkait dengan penelitian ini telah dilakukan seperti yang dilakukan oleh Agus Takariawan dan Sherly Ayuna Putri di tahun 2018, dengan judul "Perlindungan Hukum terhadap Korban Human Trafficking dalam Perspektif Hak Asasi Manusia", diterbitkan dalam Jurnal Hukum IUS QUIA IUSTUM Volume 25 Nomor 2, kemudian oleh Lathifah Hanim dan Adityo Putro Prakoso di tahun 2015 dengan judul "Perlindungan Hukum Terhadap Korban Kejahatan Perdagangan Orang (Studi Tentang Implementasi Undang-Undang No. 21 Tahun 2007)", diterbitkan dalam Jurnal Pembaharuan Hukum Volume II Nomor 2, dan penelitian oleh Herlien C. Kamea di tahun 2016, dengan judul "Penegakan Hukum Pidana Terhadap Kejahatan Perdagangan Orang Menurut Undang - Undang Nomor 21 Tahun 2007", diterbitkan dalam Jurnal Lex Crimen Volume V Nomor 2. Namun penelitian saat ini dan penelitian sebelumnya memiliki fokus yang berbeda. Walaupun sama-sama terkait dengan tindak pidana human trafficking namun fokus penelitian saat ini adalah pertanggungjawaban korporasi terhadap tindak pidana human trafficking. 


$\begin{array}{lr}\text { Mengingat } & \begin{array}{r}\text { kurangnya } \\ \text { tentang } \\ \text { penelitian } \\ \text { pertanggungjawaban } \\ \text { korporasi }\end{array} \\ \text { terhadap tindak pidana human } \\ \text { trafficking membuat pembahasan } \\ \text { mengenai } \quad \text { pertanggungjawaban } \\ \text { korporasi terhadap tindak pidana } \\ \text { human trafficking menjadi hal yang } \\ \text { selalu penting dan aktual untuk } \\ \text { dilakukan pengkajian. }\end{array}$

\section{PERUMUSAN MASALAH}

Rumusan masalah yang menjadi identifikasi dalam penelitian ini adalah sebagai berikut: 1). Bagaimanakah landasan korporasi dinyatakan sebagai subjek hukum dalam tindak pidana human trafficking?; dan 2). Bagaimana pertanggungjawaban korporasi dalam tindak pidana human trafficking?.

\section{Metode Penelitian}

Metode penelitian yang digunakan adalah yuridis normatif. Jenis data yang digunakan adalah data sekunder. Data sekunder berupa data yang diperoleh dari studi kepustakaan berupa bahan-bahan hukum seperti peraturan perundangundangan, buku, jurnal atau bahan seminar dengan menggunakan analisis kualitatif (Salim \& Nurbani, 2014).

\section{Pembahasan}

\section{Korporasi Sebagai Subjek Hukum Dalam Tindak Pidana Human Trafficking}

Permasalahan

pertanggungjawaban korporasi sebagai pelaku tindak pidana adalah suatu hal yang tidak sederhana mengingat permasalahan ini berpangkal pada asas tiada pidana tanpa kesalahan. Mens rea atau kesalahan adalah sikap batin, yang secara alamiah hanya ada pada orang alamiah saja dan oleh sebab itu, maka dipandang hanya manusia alamiah yang bisa dimintakan pertanggungjawaban pidana (Ratomi, 2018).

Khazanah hukum Romawi kesatuan korporasi disebut universitas, yang di dalamnya termasuk negara, kotamadya dan asosiasi atau perkumpulan swasta. Asas societas delinquere non potest dikenal saat itu dimana universitas tidak sama dengan manusia yang memiliki kemauan dan jiwa, universitas merupakan fiksi yang tidak memiliki badan dan jiwa dan karenanya tidak dapat dipidana (Sjawie, 2017).

Asas societas delinquere non potest inilah yang menjawab mengapa dalam KUHP tidak ditemukan tempat bagi korporasi sebagai subjek hukum. Subjek hukum adalah segala sesuatu yang dapat mempunyai hak dan kewajiban. Hak adalah kekuasaan, kewenangan yang diberikan oleh hukum kepada subjek hukum sedangkan kewajiban adalah beban yang diberiakan oleh hukum kepada subjek hukum (Amirullah, 2012). Pada awalnya, yang dapat dipandang sebagai subjek hukum pidana oleh pembuat UndangUndang adalah bahwa hanya manusia 
(orang-perorangan atau individu). Subjek hukum pidana yang dikenal dalam Kitap Undang-Undang Hukum Pidana (KUHP) yaitu orangperseorangan. Pemikiran korporasi belum dipandang sebagai subjek hukum pidana, namun dalam perkembangannya, korporasi sudah dianggap sebagai subjek hukum pidana (Ratomi, 2018). Dimana pada kenyataannya bahwa manusia terkadang melakukan tindak pidana melalui organisasi sehigga pembuat Undang-Undang dalam merumuskan delik turut memperhitungkan kenyataan ini (Suhariyanto, 2017).

Kaitannya dengan Rancangan Konsep KUHP Nasional, maka nilainilai Pancasila harus meresap kedalam pasal-pasal konsep KUHP Nasional. Oleh karena itu, korporasi di dalam RUU KUHP diterima sebagai subjek hukum pidana. Saat ini subjek hukum pidana tidak dibatasi tehadap orang-perorangan (natural person) saja melainkan mencakup pula korporasi.

Istilah korporasi dalam hukum Indonesia atau biasa disebut Perseroan Perdata hanya dikenal dalam Hukum Perdata, dan telah didudukan sebagai subjek hukum. Dalam Pasal 1654 Kitap UndangUndang Hukum Perdata, disebutkan bahwa korporasi dapat didefinisikan sebagai "perseroan perdata adalah suatu persetujuan antara dua orang atau lebih, yang berjanji untuk memasukan sesuatu ke dalam perseroan itu dengan maksud supaya keuntungan yang diperoleh dari perseroan itu dibagi di antara mereka".

Sekalipun bukan manusia (person), korporasi (rechtperson) merupakan subjek hukum yang memiliki hak-hak dan kewajiban sendiri, dalam hal ini berbentuk sebagai badan hukum atau organisasi yang terdiri dari sekumpulan orang yang bergabung untuk suatu tujuan tertentu serta memiliki kekayaan tertentu. Maka dari itu dalam lalu lintas hukum maka badan hukum tersebut diwakili oleh pengurus yang bertindak untuk dan atas nama serta demi kepentingan badan hukum tersebut (mewakilinya). Terkait dengan korporasi sebagai subjek hukum, korporasi yang memiliki hakhak dan kewajiban mampu melakukan tindak pidana yang dapat dimintai pertanggungjawabannya (Ratomi, 2018).

Perkembangan di dalam ilmu hukum pidana telah diterima dengan baik di kalangan akademisi ataupun kalangan praktisi mengenai suatu kejahatan khusus yang melibatkan suatu perusahaan yang disebut corporate crime (kejahatan korporat). Terkadang untuk kejahatan korporasi ini juga disebut kejahatan korporasi atau kejahatan organisasi (organizational crime) (Amirullah, 2012).

Dewasa ini penyebutan korporasi terus berkembang dan banyak ditemui diberbagai buku karangan. Bahkan di Indonesia, dalam berbagai ketentuan aturan hukum yang dikeluarkan oleh pemerintah 
juga mencantumkan kata-kata korporasi misalnya, dalam UndangUndang Nomor 31 Tahun 1999 tentang Pemberantasan Tindak Pidana Korupsi sebagaimana yang telah diubah menjadi Undang-Undang Nomor 20 Tahun 2001 (UU Tipikor), Undang-Undang Nomor 32 Tahun 2009 tentang Perlindungan Dan Pengelolaan Lingkungan Hidup (UU Lingkungan Hidup), Undang-Undang Nomor 31 Tahun 2004 tentang Perikanan (UU Perikanan), UndangUndang Nomor 21 Tahun 2007 tentang Pemberantasan Tindak Pidana Perdagangan Ordan peraturan perundang-undangan lainya.

Dengan demikian korporasi sebagai subjek tindak pidana yang berbadan hukum ataupun non-badan hukum dianggap mampu melakukan tindak pidana (corporate crime) yang mampu memberikan dampak kerugian dan dapat dimintakan pertanggung-jawabannya dalam hukum pidana (Suhariyanto, 2017). RUU KUHP yang baru telah meletakan pengertian tentang korporasi dalam Pasal 45 sampai dengan Pasal 50 yang mana korporasi dapat dijadikan sebagai pelaku kejahatan dan dapat dibebani pertanggungjawaban. Keberadaan korporasi dapat dijadikan pelaku tindak pidana dapat disimpulkan dari beberapa pasal di dalam RUU KUHP, yakni: 1).Secara prinsip dalam RUU KUHP, konsep korporasi telah diterima sebagai badan hukum yang dapat dijadikan subjek hukum pidana; 2).Dengan demikian korporasi sebagai badan hukum dapat dituntut dan dijatuhi hukuman pidana; 3).Tindak pidana yang bisa dipertanggungjawabkan kepada korporasi adalah semua perbuatan yang termasuk tindak pidana yang dilakukan oleh orang-orang yang mempunyai kedudukan fungsional (functioneel daders) dalam korporasi yang melakukan perbuatan itu dalam lingkungan usaha dari korporasi sesuai dengan anggaran dasarnya; dan 4).Hanya sebagaian peraturan perundang-undangan dapat diterapkan atas korporasi, misalnya tidak mungkin menerapkan sanksi pidana penjara atau pidana mati atas korporasi (Ratomi, 2018).

Kaitannya dengan banyaknya pengaturan khusus mengenai korporasi yang melakukan tindak pidana maka pengaturan tersebut diatur juga dalam UU mengenai tindak pidana human trafficking yaitu yang telah diatur sebagaimana dalam Undang-Undang Nomor 21 Tahun 2007 tentang Pemberantasan Tindak Pidana Perdagangan Orang mengenal adanya dua subjek hukum yaitu orang-perseorangan (person) dan korporasi (recht person). Rumusan pasal mengenai subjek hukum dapat kita lihat dalam rumusaan Pasal 1 Angka 4 yang menyebutkan "Setiap Orang adalah orang perseorangan atau korporasi yang melakukan tindak pidana perdagangan orang". Dengan demikian dapat kita mengerti UU ini mengenal subjek hukum meliputi manusia dan korporasi baik yang 
berbadan hukum ataupun tidak berbadan hukum.

Terkait dengan pengaturan tersebut, maka pengaturan tersebut harus memuat sanksi pidana bagi korporasi. Karena korporasi itu tidak mempunyai wujud badan secara lahiriah, maka sanksi pidana yang bisa diberikan kepadanya bukanlah sanksi pidana klasik, kecuali sanksi yang berkaitan dengan denda atau pinalti.

Pada umumnya pengenaan denda kepada korporasi ini akan optimal mengingat pengeksekusiannya cukup mudah, apalagi bila sebelumnya telah diadakan penyitaan terhadp harta korporasi yang dianggap cukup ereat bersinggungan dengan tindak pidana yang terbukti telah dilakukannya (Amirullah, 2012).

Selain pengenaan hukuman pokok berupa denda, maka bisa sja kepada korporasi itu diberikan hukuman tambahan dalam berbagai bentuknya, seperti pencabutan izin sementara waktu, atau pelarangan melakukan usaha tertentu dalam waktu tertentu, ataupun pembubaran korporasi bersangkutan.

\section{Pertanggungjawaban Korporasi} Terhadap Tindak Pidana Human Trafficking

Diundangkannya Undang-

Undang 21 Tahun 2007 tentang Pemberantasan Tindak Pidana

Perdagangan Orang pada tanggal 19 April 2007, rumusan tentang perdagangan orang/human trafficking yang terdapat di dalam UU ini menjadi rujukan utama. Pasal 1 angka 1 menyebutkan "Perdagangan Orang adalah tindakan perekrutan, pengangkutan, penampungan, pengiriman, pemindahan, atau penerimaan seseorangdengan ancaman kekerasan, penggunaan kekerasan, penculikan, penyekapan, pemalsuan, penipuan, penyalahgunaan kekuasaan atau posisi rentan, penjeratan utang atau memberi bayaran atau manfaat, sehingga memperoleh persetujuan dari orang yang memegang kendali atas orang lain tersebut, baik yang dilakukan di dalam negara maupun antar negara, untuk tujuan eksploitasi atau mengakibatkan orang tereksploitasi".

Atas definisi tersebut, terkandung makna bahwa manusia dijadikan komiditas, memindahkannya dengan semenamena, sarat dengan berbagai pelanggaran dan tindak kejahatan dengan kesewenang-wenangan yang berlandaskan kekuasaan dengan tujuan ekspolitasi tenaga kerja untuk berbagai kepentingan yang merugikan korban dan menguntungkan pihak lain. Maka dari itu, human trafficking merupakan kejahatan kemanusian yang harus segera dihentikan (Sularman \& Ma'ruf, 2017).

Undang-Undang Nomor 21 Tahun 2007 memuat unsur dari tindak pidana human trafficking, yaitu dengan kekerasaan atau acaman kekerasaan, penipuan, penculikan, penyekapan, penyalahgunaaan kekuasaan, pemanfaatan posisi kerentanan atau 
penjeratan utang. Sehubungan dengan hal tersebut, bahwa peristiwaperistiwa pidana memiliki unsurunsur adalah suatu kelakuan yang bertentangan dengan (melawan) hukum, suatu kelakuan yang diadakan karena suatu pelanggar bersalah dan suatu kelakuan yang dapat dihukum, maka dalam tindak pidana human trafficking terdapat perbuatan yang melawan hukum yaitu melakukan perbuatan merekrut, mengirim, dan penyerah terimaan dengan kekerasaan atau ancaman kekerasaan, penipuan, penculikan, penyekapan, penyalahgunaaan kekuasaan, pemanfaatan posisi rentan atau penjeratan atas unsur kesalahan dalam rumusan tindak pidana human trafficking adanya kesalahan digambarkan secara implisit dalam rumusan untuk tujuan mengeksploitasi atau berakibat tereksploitasi orang tersebut yang berarti ada maksud untuk mengeksploitasi atau berakibat tereksploitasi orang tersebut (Kamea, 2016).

Terkait pengaturan mengenai pertanggungjawaban korporasi dalam tindak pidana human trafficking telah diatur dalam Pasal 13 UU ini, yaitu: “Ayat (1).Tindak pidana perdagangan orang dianggap dilakukan oleh korporasi apabila tindak pidana tersebut dilakukan oleh orang-orang yang bertindak untuk dan/atau atas nama korporasi atau untuk kepentingan korporasi, baik berdasarkan hubungan kerja maupun hubungan lain,bertindak dalam lingkungan korporasi tersebut baik sendiri maupun bersama-sama"; dan "Ayat (2). Dalam hal tindak pidana perdagangan orang dilakukan oleh suatu korporasi sebagaimana dimaksud pada ayat (1), maka penyidikan, penuntutan, dan pemidanaan dilakukan terhadap korporasi dan/atau pengurusnya".

Melihat ciri kejahatan korporasi yang berbeda dengan kejahatan yang dilakukan perorangan. Sehingga terdapat beberapa teori tentang pertanggungjawaban pidana korporasi. Hal ini bukan saja karena korporasi merupakan organisasi, akan tetapi juga karena tujuan korporasi adalah untuk melakukan bisnis dan bukan melakukan kejahatan, maka persoalan masalah mens rea atau sikap batin tidaklah semudah apabila dibandingkan dengan kejahatan yang dilakukan oleh perorangan (Azizurrahman, 2014).

Ada 2 teori yang digunakan sebagai landasan pembenaran dibebankannya pertanggungjawaban pidana kepada korporasi, karena dalam dua teori ini tetap menempatkan kesalahan sebagai syarat dapat dipertanggunjawabkannya suatu subjek pidana, yaitu:

Pertama, Teori Identifikasi. Teori dipergunakan untuk memberikan pembenaran bagi pembebanan pertanggungjawaban pidana pada korporasi meskipun pada kenyataannya korporasi bukanlah sesuatu yang dapat berbuat sendiri dan tidak mungkin memiliki 
mens rea karena memang tidak memiliki sikap batin (Azizurrahman, 2014).

Teori ini mengajarkan bahwa untuk dapat membebankan pertanggungjawaban pidana kepada suatu korporasi, siapa yang melakukan tindak pidana tersebut harus mampu diidentifikasikan oleh penuntut umum. Apabila tindak pidana human trafficking tersebut dilakukan oleh mereka yang merupakan directing mind dari korporasi tersebut, maka pertanggungjawaban tindak pidana itu baru dapat dibebankan kepada korporasi. Artinya prilaku dan mens rea dari seseorang yang terkait dengan suatu korporasi dapat diatributkan kepada korporasi agar pertanggungjawaban pidana dapat dibebankan kepada korporasi tersebut. Dengan kata lain, prilaku dan mens rea dari orang tersebut dianggap merupakan prilaku dan sikap kalbu dari korporasi tersebut. Penentuan untuk dapat menerapkan teori ini harus dapat ditujukan bahwa: 1).Perbuatan dari personel yang menjadi directing mind korporasi termasuk dalam bidang kegiatan yang ditugaskan kepadanya; 2).Perbuatan pidana tersebut bukan merupakan kecurangan terhadap korporasi yang bersangkutan; 3).Perbuatan pidana itu dimaksudkan untuk memperoleh atau menghasilkan manfaat bagi korporasi; dan 4).Agar subjek hukum dapat dinyatakan bersalah karena telah melakukan perbuatan pidana, subjek hukum tersebut harus memiliki kesalahan (Hanim \& Prakoso, 2015).

Kedua, Teori Vicarious Liability. Teori ini menguatkan akan adanya pembenaran bagi pembebanan pertanggungjawaban pidaana kepada korporasi. Teori ini merupakan pembebanan pertanggungjawaban pidana dari tindak pidana yang dilakukan, oleh orang lain atau lebih dikenal dengan pertanggungjawban penganti. Pada vicarious liability, mens rea menjadi syarat utama yang harus dipenuhi untuk memidana subjek hukum yang melakukan pidana. Dengan kata lain harus dibuktikan terlebih dahulu bahwa seseorang melakukan kesalahan, sehingga ia patut dipidana atas kesalahanya tersebut. Selain itu harus ada hubungan kerja antara pelaku dengan orang lain yang harus mempertanggungjawabkan perbuatan pidana yang dilakukan (Azizurrahman, 2014).

Apabila teori ini diterapkan pada korporasi, berarti korporasi dimungkinkan harus bertanggungjawab atas perbuatanperbuatan yang dilakukan oleh para pegawainya, kuasanya, atau mandatarisnya atau siapapun yang bertanggungjawab kepada korporasi tersebut. Terdapat dua syarat penting yang harus dipenuhi untuk dapat menerapkan suatu perbuatan pidana berdasarkan teori ini, yaitu: 1).Harus terdapat suatu hubungan, seperti hubungan pekerjaan antara majikan dengan pekerja; dan 2).Perbuatan pidana yang dilakukan oleh pekerja 
tersebut harus berkaitan atau masih dalam ruang lingkup pekerjaanya (Girsang, 2014).

Jika teori ini dihubungkan dengan kejahatan korporasi, hal demikian adalah bagian dari upaya untuk mejerat korporasi atas tindak pidana yang dilakukan pegawainya. Pembebanan pertanggung-jawaban pidana yang dibebankan kepada atasan (direktur) atas perbuatan pidana yang dilakukan oleh bawahanya dalam sebuah struktur organisasi, dikarenakan perbuatan pegawai merupakan bagian dari untuk kepentingan korporasi itu sendiri. Sehingga dengan sendirinya pertanggungjawaban tersebut dibebankan kepada atasan atau direktur yang dalam hal ini bertindak untuk dan atas nama korporasi (Kamea, 2016).

Di era globalisasi dimana kejahatan sudah bertransformasi dari model konvensional ke model modern, alangkah bijaknya apabila kita sudah mulai melirik korporasi sebagi subjek hukum dan dapat dipertanggungjawabkan secara pidana. Apalagi dalam hal tindak pidana human trafficking, sangat dimungkinkan korporasi mendapatkan keuntungan ekonomi dari terjadinya tindak pidana human trafficking (Girsang, 2014).

Berdasarkan 2 teori diatas dan sesuai dengan bunyi rumusan pasal 13 Undang-Undang Nomor 21 tahun 2007, maka teori Vicarious Liability lebih tepat jika digunakan dalam memintakan pertanggungjawaban pidana terhadap korporasi dalam tindak pidana human trafficking.

Membicarakan mengenai pertanggungjawaban pidana korporasi yang melakukan tindak pidana human trafficking dalam menganalisisnya juga menggunakan teori pertanggungjawban pidana secara umum, sebagai berikut: 1).Memiliki kemampuan pertanggungjawaban; 2).Adanya kesalahan baik sengaja maupun kealpaan; dan 3).Tidak ada hal-hal yang merupakan alasan penghapus pidana.

Menerapkan teori diatas tetap berpedoman dengan kaidah mengenai pertanggungjawaban korporasi sebagai subjek hukum, sehingga sesuai dan relevan. Untuk memahami secara keseluruhan maka kriteria pertanggungjawaban diatas akan diuraikan satu persatu, yaitu:

Pertama,

Memiliki

Kemampuan Pertanggungjawaban. Secara sederhana, istilah "kemampuan bertanggungjawab" dapat diartikan sebagai "Kondisi sehat dan mempunyai akal seseorang dalam membedakan hal-hal yang baik dan yang buruk". Pada Prinsipnya, dalam persoalan kemampuan bertanggungjawab ini hukum pidana menganut sistem yang disebut dengan "sistem fiktif" artinya, menurut hukum Indonesia tiap-tiap pelaku perbuatan pidana pada dasarnya selalu diangap sebagai orang yang mampu bertanggungjawab atas perbuatannya (Takariawan \& Putri, 2018). 
Maka dari itu, setiap perbuatan pidana yang dilakukan oleh organ korporasi seperti karyawan, direktur, komisaris, pemegang saham, atau siapapun yang sebagai pengendali dari korporasi, mereka dianggap sebagai orang yang mampu bertanggungjawab atas perbuatannya, kecuali apabila dapat dibuktikan sebaliknya pada dirinya terdapat alasan sebagaimana tercantum dalam pasal 44 KUHP yaitu: 1).Jiwa pelaku mengalami cacat mental sejak pertumbuhannya hingga akalnya menjadi kurang sempurna untuk membedakan antara baik dan yang buruk; dan 2).Jika pelaku mengalami gangguan kenormalan yang disebabkan oleh suatu penyakit, hingga akalnya menjadi tidak berfungsi secara sempurna/optimal untuk membedakan hal-hal yang baik dan yang buruk.

Rumusan diatas dikaitkan dengan pertanggungjawaban korporasi sebagai subjek hukum dalam Undang-Undang No 21 tahun 2007, dengan menggunakan teori vicarious liability maka kemampuan bertanggungjawab organ korporasi (karyawan, direktur, komisaris, pemegang saham, atau siapapun yang sebagai pengendali dari korporasi) selama dalam tugas, perintah atau tujuan dari korporasi dilimpahkan menjadi kemampuan bertanggungjawab korporasi. Korporasi sebagai majikan dari organ tersebut.

Kedua, Adanya Kesalahan Baik Kesengajaan atau Kealpaan. Dalam hukum pidana sengaja (dolus) atau kealpaan (culpa) adalah dua bentuk sikap batin dari seorang pelaku perbuatan pidana yang menjadi dasar penting untuk menentukan apakah ia bersalah atau tidak atas perbuatannya. Inti dalam teori ini ialah perbuatan pidana seseorang sudah dapat dikatakan sengaja dilakukan jika saat berbuat pelaku tersebut mengetahui/ menyadari bahwa perbuatan itu merupakan yang dilarang oleh hukum dan teori ini mengajarakan perbuatan pidana seseorang baru dapat dikatakan sengaja dilakukan jika saat berbuat pelaku tersebut tidak saja mengetahui/menyadari terlarangnya perbuatan, tetapi juga memang menghendaki terjadinya perbuatan itu (Takariawan \& Putri, 2018).

Ketiga, Tidak ada Alasan Pemaaf dam Pembenar Sebagai Penghapus Kesalahan. Syarat suatu subjek hukum termasuk korporasi dapat dipertangung-jawabkan secara pidana yang terakhir ialah mengenai tidak adanya alsan pemaaf. Alasan pemaaf adalah alasan yang menghapuskan kesalahan suatu subjek hukum termasuk korporasi. Perbuatan yang dilakukan oleh subjek hukm (korporasi) tetap melawan hukum jadi tetap merupakan perbuatan pidana, tetapi tidak dipidana, karena tidak ada kesalahan (Azizurrahman, 2014).

Sesuai dengan sifat kemandirian (persoonelijk) alasanalasan penghapus pidana harus dicari pada korporasi itu sendiri. Mungkin sekali terjadi pada diri seseorang 
terdapat alsan penghapus pidana tetapi tidak demikian halnya pada korporasi, sekalipun berbuat orang tersebut telah diangap sebagai perbuatan korporasi.

Dengan demikian bagaimana pertanggungjawaban korporasi dalam tindak pidana human trafficking ialah terpenuhinya semua syaratsyarat pertanggungjawaban pidana yang diinterpretasikan dari kesalahan para pengurusnya yang sudah diuraikan diatas yaitu, adanya tindak pidana/perbuatan pidana, adanya kemampuan bertagggungjawab, adanya kesalahan, dan tidak ada alasaan penghapus pidana. Kemudaian disesuaikan dengan teori pertangungjawaban korporasi sebagaimana sudah diuraikan dan dijelaskan diatas (Azizurrahman, 2014).

Sebagai tindak lanjut dari terpenuhinya syarat korporasi dapat dibebankan pertanggungjawaban pidana, maka Undang-Undang Nomor 21 tahun 2007, telah mengatur sanksi pidana berupa sanksi pidana denda dan sanksi pidana tambahan. Rumusan sanksi tersebut disebutkan dalam Pasal 13 Ayat 1 dan 2 yaitu: “Ayat (1).Tindak pidana perdagangan orang dianggap dilakukan oleh korporasi apabila tindak pidana tersebut dilakukan oleh orang-orang yang bertindak untuk dan/atau atas nama korporasi atau untuk kepentingan korporasi, baik berdasarkan hubungan kerja maupun hubungan lain, bertindak dalam lingkungan korporasi tersebut baik sendiri maupun bersama-sama"; dan "Ayat (2).Dalam hal tindak pidana perdagangan orang dilakukan oleh suatu korporasi sebagaimana dimaksud pada ayat (1), maka penyidikan, penuntutan, dan pemidanaan dilakukan terhadap korporasi dan/atau pengurusnya".

\section{Penutup \\ Kesimpulan}

Korporasi sebagai subjek hukum pidana dapat dipersamakan dengan manusia. Karena di dalamnya terdapat hak dan kewajiban yang diberikan oleh hukum, dan karenanya kecakapan korporasi juga dipersamakan dengan kecakapan manusia yang terlihat didalamnya. Korporasi telah ditentukan sebagai subjek hukum tindak pidana oleh RUU KUHP, yang mana nantinya akan berlaku keseluruh sistem hukum pidana. Diakibatkan hal itu setiap perundang-undangan diluar KUHP tidak perlu lagi mengatur secara khusus, kecuali perundang-undangan diluar KUHP itu ingin menentukan lain atau menyimpang.

Secara hukum pidana, baik dilihat dalam Undang-Undang Nomor 21 tahun 2007 tentang Pemberantasan Tindak Pidana Perdagangan Orang maupun teori-teori pertanggungjawaban korporasi, korporasi sebagai salah satu subjek hukum dalam tindak pidana human trafficking dapat dimintakan pertanggungjawbannya apabila melakukan tindak pidana human trafficking. Dalam menentukan 
pertanggungjawban korporai yang melakukan tindak pidana perdagangan orang ditentukan dari terpenuhinya syarat pertanggungjawban pidana asecaa umum (syarat subjektif) seperti adanya kemampuan bertanggungjawab, adanya kesalahan baik kesengajaan maupun kealpaan, tidak adanya hal-hal yang dijadikan alasan penghapus pidana. Tentunya dalam menentukan bagaimana pertanggungjawabannya disesuaikan berdasarkan teori mengenai pertanggungjawaban pidana korporasi dalam hal tindak pidana human trafficking lebih tepat jika digunakan teori vicarious liabillity dalam menentukan pertanggungjawaban korporasi dalam tindak pidana human trafficking.

\section{Daftar Pustaka}

Buku

Salim, H., \& Nurbani, E. S. 2014. Penerapan Teori Hukum Pada Penelitian Tesis dan Disertasi. Jakarta: PT. Raja Grafindo Persada.

Sjawie, Hasbullah F., 2017, Pertanggungjawaban Pidana Korporasi Pada Tindak Pidana Korupsi, Kencana, Jakarta

\section{Jurnal}

Amirullah. 2012. Korporasi Dalam Perspektif Subyek Hukum Pidana . Al-Daulah: Jurnal Hukum Dan Perundangan Islam, VOL.2 NO.2, pp. 139-160.

Azizurrahman, S. H. 2014. Pembaharuan Kebijakan Pidana
Kejahatan Perdagangan Orang (Studi Di Wilayah Perbatasan Kalimantan Barat-Sarawak). Jurnal Yustisia, Vol. 3 No.2, pp.88-99.

Girsang, H. 2014. Pemberantasan Tindak Pidana Perdagangan Orang Melalui Undang-Undang Pencegahan Dan Pemberantasan Tindak Pidana Pencucian Uang. Jurnal Ilmu Hukum, pp.111-138.

Hanim, L., \& Prakoso, A. P. 2015. Perlindungan Hukum Terhadap Korban Kejahatan Perdagangan Orang (Studi Tentang Implementasi Undang-Undang No. 21 Tahun 2007). Jurnal Pembaharuan Hukum, Vol.II No.2, pp. 234-244.

Kamea, H. C. 2016. Penegakan Hukum Pidana Terhadap Kejahatan Perdagangan Orang Menurut Undang - Undang Nomor 21 Tahun 2007. Jurnal Lex Crimen, Vol.V No.2, pp.126-132.

Nugroho, O. C. 2018. Tanggung Jawab Negara Dalam Penanganan Tindak Pidana Perdagangan Orang (State's Responsibility In Mitigation Of Human Trafficking Crime) . Jurnal Penelitian Hukum De Jure, Vol.18 No.4, pp.543-560.

Ratomi, A. 2018. Korporasi Sebagai Pelaku Tindak Pidana (Suatu Pembaharuan Hukum Pidana Dalam Menghadapi Arus Globalisasi Dan Industri). Jurnal Hukum Al'Adl, Vol.10 No.1, pp. 1-22. 
Suhariyanto,

B.

2017.

Pertanggungjawaban Pidana

Semarang, tanggal

21

Korporasi

Berdasarkan

Corporate Culture Model Dan

Implikasinya

Bagi

Kesejahteraan Masyarakat.

Jurnal Rechts Vinding, Vol.6

No.3, pp. 441-458.

Sularman, A., \& Ma'ruf, U. 2017.

Pertanggungjawaban Pidana

Korporasi Kepada Korban

Tindak Pidana . Jurnal Hukum

Khaira Ummah, Vol.12 No.2, pp.387-396.

Takariawan, A., \& Putri, S. A. 2018.

Perlindungan Hukum

Terhadap Korban Human

Trafficking dalam Perspektif

Hak Asasi Manusia. Jurnal

Hukum IUS QUIA IUSTUM,

Vol.25 No.2, pp. 237- 255.

\section{Bahan Ajar Seminar Nasional}

Gitasari Retno Widowati, Kasubit

Kawasan III, Dit. Perlindungan

WNI dan BHI Kementrian Luar

Negeri, judul: Perlindungan WNI

di Luar Negeri, pada Seminar

Nasional dengan tema

Perlindungan Hukum

Terhadap Tenaga Kerja

Indonesia Korban Human

Trafficking di MIH Undip

Semarang, tanggal 21

November 2018.

Nurharsono, Koord. Devisi Bantuan

Hukum, Migrant CARE

Jakarta, judul: Realita

Perlindungan TKI Dari Tindak

Pidana Human Trafficking, pada

Seminar Nasional dengan tema

Perlindungan Hukum

Terhadap Tenaga Kerja

Indonesia Korban Human

Trafficking di MIH Undip 